\title{
An Analysis of Teaching Sustainable Development Values (SDVs) at Madrassah
}

\author{
* Rukhsana Raza, PhD Scholar \\ ** Ashfaque Ahmad Shah, Assistant Professor (Corresponding Author) \\ *** Dr. Muhammad Sarwar, Professor
}

\begin{abstract}
The current study aimed to analyze prevailing notions and understanding of Madrassahs' heads, teachers, and students about on-going teaching practices of Sustainable Development Values (SDVs). It was done by analyzing the expectation and prevalence of teaching practices of SDVs. Diversified methods' approach was considered best appropriate, using an amalgamation of two methods known as qualitative and quantitative approaches. The population was all administrators, teachers, and students enrolled in Shahadat-ul-Alia and Shahadat-ul-Almia of the Madrassahs of the Punjab, Pakistan. The multistage sampling technique was used for the selection of the respondents. Three instruments were used: first and second instruments were self-developed questionnaires, consisting of 17 items both for teachers and students used to collect quantitative data. The third instrument which was a viable method known as interview schedule was used to gather qualitative data to triangulate the results obtained from the quantitative data. Moreover, it has been deducted from the given study that heads of departments, mentors, and learners of the Madrassahs consist of unanimous views that the expectations for teaching SDVs are significantly greater than the prevailing teaching practices of SDVs. It leads to the conclusion that there is a more need for teaching Sustainable Development Values to the Madrassah students.
\end{abstract}

Keywords: Expectation, Prevalence, Sustainable Development, Teaching, Madrassah Introduction

Value is a moral concept that enables an individual to bring a distinction between good and bad. Moreover, it is pertinent to mention that values are not innate rather they are always learned. They are learned through socialization, experience, and practices with family and inside educational setting (Bergmark, 2007). According to Campbell and Murray (2004), values contribute a significant role in the development of human personality. As we know, human personality is idealized by the fulfilment of three main aspects, which are cognitive, affective, and psychomotor. Moreover, cognition is all about the mind or human thoughts. One needs to have support from values in order to give practical shape to these human thoughts which are abstract mental concepts or 'ideas'. On the other hand, the affective domain involves feelings, emotions, and attitudes, in which these feelings are addressed with the cooperation of values. This has also been verified in Bloom's Taxonomy. Lastly, the psychomotor domain is also of paramount importance which prevents problems due to the strong influence of values.

Values are the most expectable beliefs and manners towards an individual from his respective society and community. Therefore, one must try one's level best in the fulfilment of the values. Values prove to be a driving force and an impetus in the guidance and amelioration of mankind. Moreover, on violating certain values an individual whether he/she feels regret and instability for survival in a society (Chilton, 2004).

It is an unfortunate dilemma that the world is in the lap of many social evils such as terrorism, corruption, intolerance, and injustice. Additionally, the root cause behind these evils is lack of moral values. Therefore, strengthening of moral values in society is necessary to uproot all these existing evils (Berkowitz, Battistich, \& Bier, 2008). Sustainable development is an integral process that contributes to ensuring the maintenance of the resources. Moreover, it is the pre-requisite process to

\footnotetext{
* Department of Education, University of Sargodha Email: rukhsanaraza.dydeo@ yahoo.com

** Department of Education, University of Sargodha Email: multanxa@ gmail.com

*** Department of Education, University of Sargodha Email: drsarwar@ymail.com
} 
achieve the greater amelioration of society. It is the systematic process that involves the stability and prevention of nature (Dekker et al., 2002).

It has been manifested from historical evidence that sustainable development values have contributed immensely to the reinforcement of the societies. Therefore, it can be rightly said that every nation envisions sustainable development values. In addition to this, sustainable development values bring close human beings and their respective society. Among them, the most vital are reinforcement of civilized societies, harmonized family systems, and value-oriented civilization. So, it has been evaluated that physical, moral, and spiritual needs can be effectively fulfilled through sustainable development values (Shah, 2008).

Shaker (2015) highlighted the vital functioning of notable international organizations (e.g. UNESCO, UNICEF, etc.). These international organizations are striving to ameliorate the existing structure of society through enlarging peace and trigging sustainable development. Moreover, UNESCO has marked and universally celebrated the years 2001 to 2010 (a decade) for the proliferation of peace, unity, higher education, and promotion of sustainable development values. To meet these respective targets, UNESCO has effectively launched various teaching and training programs for learning sustainable development. These programs subsequently lead to the fulfilment of desired learning objectives. According to the UNESCO, it is based on all levels and types of learning learning to know, learning to be, learning to live together, learning to do and learning to transform oneself and society (UNESCO, 2019). It tends to contribute to its development and utilizing the diversity represented by all people. It also includes people who have been or feel marginalized. It is related to generate innovative solutions to sustainable development challenges and crises (Singh, 2007).

On the other hand, the modern concept of sustainable development has been mainly deducted from the 'Brundtland Report of 1987' based on protecting the environment and its resources. Then, various changes have been taken place in its form. There has been observed a transition in the preservation of resources from natural to economic and social development for the sake of future generations. Moreover, it has been stressed greatly that the phenomenon of 'sustainability' should be meant for meeting the massive goals of humanity and bringing equilibrium in an ecosystem (Brundtland, 1987). In addition to this, sustainable development is based on the entire process of achieving sustainability in a given time and existing natural conditions. Sustainable development values are unique as they tend to bring greater learning and teaching objectives. Moreover, it has been suggested to enlarge its utility for achieving a goal of community and cultural progression. It is also an admitted fact that the effectiveness of sustainable development will expand only when fulfilling the basic needs and aspirations of people and society. Sustainability should not be two-folds. Firstly, it must consider the basic desires of the community existing at the given time. Secondly, the needs of the future's community should also not be undermined (Brundtland, 1987).

The process of sustainable development is a systematic and pedagogical learning approach. Education for sustainable development is contributing to nourishing teachers' and learners' basic understanding of the various concepts. It also aids in maturing skills, knowledge, expertise, and thoughts about the related environment, natural setting, and broad society. Education for sustainable development is an ideal process to make an individual more competent and capable to fulfil his social, moral, spiritual as well as economic needs. It helps an individual in materializing a resourceful source of livelihood (Raco, 2005).

Marope, Chakroun, and Holmes (2015) examined the various dimensions of education pertinent to sustainable development. It is highly beneficial for society and existing natural resources. Furthermore, UNESCO has advanced key goals of sustainable development. Among them, the most vital is the protection and preservation of natural climate and its changes, managing disasters, eliminating poverty, guarding human resources ensuring massive human participation, and acknowledging biodiversity. In addition to this, it as another objective reinforcing human behaviour through ensuring greater students' and teachers' participation in learning and training. Lastly, it caters to the grievances of learners and teachers by providing them a competent, safe, and healthy learning environment for active learning, participation, and decision-making. 


\section{Significance of the Study}

The present study will add to the limited body of research regarding the expected and prevailing teaching practices of Sustainable Development Values (SDVs) at Madrassahs of Punjab. It is expected that the findings of the current research would be very advantageous for researchers, instructional designers, policymakers, curriculum developers, teachers, and students to plan the prospect investigation and activities.

\section{Statement of the Problem}

Education plays an extraordinary role in human lives. It adds quality to our lives. Moreover, it shapes the destiny of an individual and the entire society. It has played an unprecedented role in improving our future's lives by preparing us for daunting challenges. An ideal and progressive society is only generated through extraordinary and educated minds, empirical researches, and reinforced moral values. Moreover, the domain of education is not only limited to learning institutions, laboratories, research centres, and libraries. Its scope is universal and vast. It covers every aspect of human life. Additionally, it is not only surrounded so few learned individuals. The education paves broad scope and utility for all classes of society. It has inclusive features that cater to the needs of the entire human society throughout the sphere of their lives. Lastly, education is not only productive to find practical solutions to prevailing problems and challenges of lives. It aims to fulfil social, cultural, moral needs as well as accomplishing physical desires. Undoubtedly, it nurtures positive and productive relations among human beings and their physical surroundings.

In addition to this, sustainable development aspires to identify capable and efficient individuals. The learned and efficient individuals must possess pivotal high moral traits to ensure the advanced learning. Among them, the traits which are a sense of responsibility, care, honest and independent decision-making are highly pertinent. The individuals must be enough courageous to tackle every type of existing socio-economic, political, and environmental issues faced by enlarged human society. Furthermore, another main objective of sustainable development is to maintain continuity or meaning coordination among various prevailing resources on the environment. However, this coordination cannot be formulated easily. It needs profound and relevant understanding and knowledge of existing social, economic, and political concerns. So, the entire epitome of the above-mentioned discussion is that system of education leads to the progression of necessary moral values \& ethical codes. These moral and ethical values are subsequently leading to improved decision-making empowered thinking and appropriate management of human resources. It has also been envisioned by the Government to achieve students especially citizens who appropriately possess extraordinary resources. This is how the goal of sustainable development can be rightfully fulfilled.

As United Nations Organization (UNO) and its subsidiary bodies (e.g. UNESCO, UNICEF, etc.) have been striving for making, keeping and building peace in the world by the help of sustainable development (UNESCO, 2019; UNICEF, 2018). So, $3^{\text {rd }}$ world countries like Pakistan tend to promote sustainable development education through its national educational policies and constitutions of Pakistan. In a sound education system, every Pakistani child must have the right to get education about leading challenges of his/her community; so, sustainable development education is need of the hour. Educationists focused on sustainable development studies or sustainable development sciences, not on sustainable development education. This situation necessitates institutionalizing sustainable development teaching activities. However, despite the recognition of sustainable development promoting values in the education policies, no proper mechanism yet exists for their teaching. This uncertain situation motivated the researcher to analyse the on-going teaching practices of sustainable development values in Madrassahs of Pakistan.

\section{The Objective of the Study}

The given study is unique due to its specific objectives. Furthermore, the objective of the underlying study was to interpret and evaluate the views and understanding of heads, mentors, and pupils of Madrassahs' regarding their prevailing styles, strategies, and practices of teaching sustainable development values.

\section{Methodology}

\section{Research Design}

The current study is significant in terms of its respective design. It applies a distinct design of the research known as a descriptive research design. This study was conducted in Madrassahs of province Punjab (Pakistan). Experimental, correlational, and causal-comparative research designs were 
considered comparatively less appropriate for this study because neither involves any manipulation, comparison of variables nor the testing of hypotheses in this study (Webb \& Chaffer, 2016). Therefore, a descriptive research design was considered best for the current study.

\section{The Population of the Study}

The current study is unique because of its systematic sampling. It involves entire heads, mentors and learners of the selected Madrassahs considered as population belongs to the province Punjab. In addition to this, the respective Madrassahs opted from Punjab from different sects.

\section{Sampling Design of the Study}

The study has accomplished a proper sampling design. The given study has involved an appropriate sampling technique known as the Multistage sampling technique applied for the sake of selecting and considering respondents for the fulfilment of the underlying objectives of the study. At the first stage, 08 Madrassahs were randomly selected from all Madrassahs of Punjab (04 from South Punjab, 04 from North Punjab). Eight Madrassahs from Punjab was consisted of following sects:
- $\quad$ Ehl-e-Sunnat
- $\quad$ Ehl-e-Hadith
- $\quad$ Deobandi
- $\quad$ Ehl-e-Tashayyu

At the second stage, from each selected Madrasah heads of madrasahs ( 8 in total), 3 teachers from each Madrasah (24 in total), and 25 students (200 in total) had been selected conveniently.

\section{Table 1}

Respondents of the Study

\begin{tabular}{lllcc}
\hline \multirow{2}{*}{ Province } & \multicolumn{1}{c}{ Madrassahs } & \multicolumn{2}{c}{ Respondents } \\
\cline { 3 - 5 } & \multirow{4}{*}{ Northern } & Teachers & Students \\
\hline \multirow{4}{*}{ Punjab } & Minhaj ul Quraan Lahore & 02 & 15 \\
& & Jamia Ashrafia Lahore & 03 & 25 \\
& & Jamia Ahle Hadis Lahore & 03 & 14 \\
& \multirow{3}{*}{ Southern } & Jamia al Muntazir Lahore & 04 & 42 \\
\cline { 3 - 5 } & & Islamia Anwar ul Aloom Multan & 01 & 47 \\
& & Khair ul Madaras Multan & 01 & 30 \\
& & Jamia Rehmania Multan & 02 & 13 \\
& & Shaheed Mutahri Multan & 03 & 15 \\
\hline
\end{tabular}

Heads of Madrassahs (Nazimeens) $=08$ (one from each Madrassah $),$ Teachers $=19$, Students $=201$

\section{Research Instruments}

Three research tools were used to accumulate the views of the heads, teachers, and students. These tools were semi-structured interview guides to heads of Madrasahs, questionnaires for teachers, and questionnaires for students. An appropriate systematic semi-structured interview schedule was formulated to figure out the clear understanding of the heads of Madrassahs regarding the teaching of Sustainable Development Values (efficiency/industry, future orientation, environmental concern, stewardship of resources, creativity, frugality, simplicity, and personal ecology) related to their undertaking Madrasahs. These perceptions were collected to explore the representation of accomplishment of the sustainable development values in reinforcing the respective curriculum of the Madrassah education system. Two questionnaires were developed; one for Madrassah teachers and the other for students. The questionnaire for Madrassah teachers was used to collect information about their practices regarding teaching SDVs. Moreover, it is also pertinent that another questionnaire was adopted to accumulate necessary data and information from the students regarding on-going sustainable development values teaching practices. The reliability of questionnaires was computed after pilot testing by applying Cronbach's Alpha. The value of Cronbach's Alpha of both teachers' and students' questionnaire was found at 0.92 . The lowest suggested value of Cronbach's alpha is 0.7 as cut off for a reliable scale, which reveals the level of consistency amongst the statements (Nunnally \& Bernstein, 1994).

\section{Data Collection}

Before starting the collection of data, the researcher sought permission from the concerning heads of the sampled Madrassahs to visit the respective institution. Before starting the interview or administration of questionnaires, the researcher described the purpose of the study and introduced the various components of the research instruments with the respondents. They were also requested to 
allow the recording of their interviews. In case of non-compliance with the recording, their views were noted down.

\section{Data Analysis}

The process of data analysis involved the analysis of the given study through thematic analysis and quantitative data approach with the aid of descriptive statistics.

\section{Results}

\section{Table 2}

Expectation of Sustainable Development Values

\begin{tabular}{llccccccc}
\hline \multicolumn{2}{c}{ Sustainable Development values } & 1 & 2 & 3 & 4 & 5 & M & Level \\
\hline 1. & Efficiency/Industry & 1.0 & 1.6 & 4.1 & 12.3 & 80.9 & 4.72 & High \\
2. & Future Orientation & 1.3 & 1.4 & 3.2 & 11.2 & 62.2 & 4.73 & High \\
3. & Environmental Concern & 1.1 & 1.6 & 5.8 & 10.2 & 81.4 & 4.70 & High \\
4. & Stewardship of Resources & 0.4 & 1.3 & 7.6 & 14.2 & 76.4 & 4.65 & High \\
5. & Creativity & 2.1 & 2.1 & 4.0 & 11.0 & 80.8 & 4.53 & High \\
6. & Frugality/Simplicity & 1.3 & 1.8 & 5.3 & 7.6 & 84.0 & 4.71 & High \\
7. & Personal Ecology & 5.6 & 4.5 & 10.5 & 13.3 & 66.3 & 4.31 & High \\
\hline & Overall & $\mathbf{1 . 8}$ & $\mathbf{2 . 0}$ & $\mathbf{5 . 8}$ & $\mathbf{1 1 . 4}$ & $\mathbf{7 6 . 0}$ & $\mathbf{4 . 6 2}$ & High \\
\hline
\end{tabular}

$N=220$, Low level (Range 1.00-2.33), Moderate level (Range 2.34-3.67), High level (Range 3.68-5.00, $1=$ Not at all, $2=$ To a small extent, $3=$ To a certain extent, $4=$ To a reasonable extent, $5=$ To a great extent, 1 to 5 are in percentage

Table 2 reflects the expectation of teaching practices of Sustainable Development Values as perceived by teachers and students of Madrassahs. Data in the table show that the respondents highly recommend the Sustainable Development Values to be taught to Madrassah students (4.62). The expectation level for each of the seven subsidiary values was also reported high.

Table 3

Prevalence of Sustainable Development Values

\begin{tabular}{lccccccc}
\hline Sustainable Development values & 1 & 2 & 3 & 4 & 5 & M & Level \\
\hline 1. Efficiency/Industry & 8.7 & 9.9 & 13.2 & 16.0 & 52.2 & 3.89 & High \\
2. Future Orientation & 8.0 & 10.1 & 12.9 & 19.0 & 50.0 & 3.93 & High \\
3. Environmental Concern & 8.7 & 9.6 & 11.6 & 20.0 & 50.2 & 3.94 & High \\
4. Stewardship of Resources & 8.4 & 8.0 & 12.4 & 18.7 & 52.4 & 3.93 & High \\
5. Creativity & 8.0 & 10.1 & 12.9 & 19.0 & 50.0 & 3.93 & High \\
6. Frugality/Simplicity & 8.4 & 3.6 & 13.8 & 16.9 & 57.3 & 4.11 & High \\
7. Personal Ecology & 5.6 & 4.0 & 13.1 & 16.5 & 60.9 & 4.24 & High \\
\hline \multicolumn{1}{c}{ Overall } & $\mathbf{8 . 0}$ & $\mathbf{8 . 0}$ & $\mathbf{1 2 . 8}$ & $\mathbf{1 8 . 0}$ & $\mathbf{5 3 . 3}$ & $\mathbf{4 . 0 0}$ & High \\
\hline
\end{tabular}

$N=220$, Low level (Range 1.00-2.33), Moderate level (Range 2.34-3.67), High level (Range 3.685.00), $1=$ Not at all, $2=$ To a small extent, $3=$ To a certain extent, $4=$ To a reasonable extent, $5=$ To a great extent, 1 to 5 are in percentage

Table 3 reflects the prevalence of teaching practices of Sustainable Development Values as perceived by teachers and students of Madrassahs. Data in the table show that the prevalence of Sustainable Development Values in teaching practices of sampled teachers was reported high (4.00). Descending order of their rank based on mean scores is as under personal ecology, environmental concern, creativity, future orientation, stewardship of resources, frugality/simplicity, efficiency/industry.

\section{Table 4}

Prevalence-Expectation Gap in Sustainable Development Values

\begin{tabular}{|c|c|c|c|c|c|}
\hline Sustainable Development Values & Mean & D & SD & $\mathbf{T}$ & $\mathbf{P}$ \\
\hline 1. Efficiency/Industry & $\begin{array}{l}4.70(\mathrm{E}) \\
3.89(\mathrm{P})\end{array}$ & 0.81 & 1.25 & 9.20 & 0.00 \\
\hline 2. Future Orientation & $\begin{array}{l}4.72(\mathrm{E}) \\
3.93(\mathrm{P})\end{array}$ & 0.79 & 1.27 & 8.89 & 0.00 \\
\hline 3. Environmental Concern & $\begin{array}{l}4.73(\mathrm{E}) \\
3.87(\mathrm{P})\end{array}$ & 0.86 & 1.41 & 8.64 & 0.00 \\
\hline 4. Stewardship of Resources & $\begin{array}{l}4.67(\mathrm{E}) \\
3.92(\mathrm{P})\end{array}$ & 0.75 & 1.10 & 9.75 & 0.00 \\
\hline 5. Creativity & $\begin{array}{l}4.58(\mathrm{E}) \\
3.79(\mathrm{P})\end{array}$ & 0.79 & 1.29 & 8.79 & 0.00 \\
\hline
\end{tabular}




\begin{tabular}{lllllll}
\hline \multirow{2}{*}{ 6. Frugality/Simplicity } & $4.76(\mathrm{E})$ & 0.80 & 1.49 & 7.70 & 0.00 \\
\multirow{2}{*}{$\begin{array}{l}3.96(\mathrm{P}) \\
\text { 7. Personal Ecology }\end{array}$} & $\begin{array}{l}4.71(\mathrm{E}) \\
4.06(\mathrm{P})\end{array}$ & 0.65 & 1.29 & 7.17 & 0.00 \\
\hline \multirow{2}{*}{ Overall } & $\begin{array}{l}\mathbf{4 . 6 8 ( E )} \\
\mathbf{3 . 9 0}(\mathbf{P})\end{array}$ & $\mathbf{0 . 7 8}$ & $\mathbf{1 . 1 4}$ & $\mathbf{9 . 7 8}$ & $\mathbf{0 . 0 0}$ \\
\hline
\end{tabular}

$d f=219, p<0.01, D=E-P ; P=$ Prevalence $; E=$ Expectation

Table 4 reflects the gap between expectation and prevalence of teaching practices of Sustainable Development Values (SDVs) in Madrassahs of Punjab as perceived by teachers and students. A paired samples t-test was applied to test the hypothesis. The results showed that the null hypothesis that 'there is no significant difference between expectation and prevalence of teaching practices of Sustainable Development Values in Madrassahs as perceived by teachers and students' was failed to be accepted. The prevalence of teaching practice of Sustainable Development Values in Madrassahs was less than the expectation of teachers and students.

A semi-structured interview schedule was used to gather the administrators' views about the expectation and prevalence of sustainable development teaching practices. The head teachers of Madrassahs were asked that 'to what extent, the content on 'sustainable development' is present in the existing curriculum? It was found from the data of their interviews that the maximum number of them believed that the content on sustainable development is already sufficiently incorporated in the curriculum.

One of the respondents viewed that

"There is no need to incorporate sustainability into the curriculum. It is already included in the curriculum. It is virtuous to be careful about resources. It is also decent to be future-oriented. But all the resources are under the control of the government; eventually, it is the entire responsibility of the government to care for these resources. The government has a whole hold on all the resources. So why should we teach about sustainable development." (Respondent 8)

One of the respondents opined

"The content on sustainable development is seldom found in the existing curriculum." (Respondent 1)

\section{Discussions and Conclusion}

The current study aimed to examine and interpret the several notions of Madrassahs' heads, teachers, and students regarding prevalent teaching exercises of sustainable development. It is no denying the fact that values of sustainable development (SD) are significant for every civilized and developed nation in the contemporary global world (Elliott, 2006). Furthermore, it has also been proved from historical evidence that those societies lived more progressively which followed these values and concepts of sustainability in letter and spirit. So, it has been proved that to live a life in compliance with sustainable development is equal to worth living. The notion of sustainability is neither a newly born nor at an evolving stage. Rather it has been fully developed and nurtured one (Elliott, 2006).

Brundtland Commission report (1987) is versatile and unique in its form as it foresees a magnificent use of the sustainable development. The report of the commission has laid down a more profound explanation of sustainable development. It has been extracted that the process is highly favourable for effective living. The commission views a more productive explanation of sustainable development. According to this report; 'sustainable development' is the means which fulfil the requirements of the contemporary world and society without hindering the prospects of upcoming generations (WCED, 1987).

Sustainable development empowers human beings in multiple ways. Firstly, it contributes to maintaining physical and mental health. Secondly, it makes individuals enough caring and supportive to value fellow human beings and their natural resources. Additionally, sustainable development proves to be highly resourceful in both formal and informal teaching methods. It plays a role in transforming proper values. These values which are resultant help to meet the present needs of individuals and preparing them for future challenges. Lastly, the concept of needs is not merely surrounded to the attainment of physical and material needs. By needs, we mean the accomplishment of respective moral, spiritual and ethical needs such as valuing relationships bringing unity, compassion, tolerance, freedom, and respect (Shah, 2008) 
Marope, Chakroun, and Holmes (2015) stressed the values of education for sustainable development because of its unending and everlasting goals. It is helpful for better decision-making and to face the upcoming future challenges. Therefore, it has been evaluated that the process is magnificent because of its versatile competencies.

As international institutions and organizations (e.g. UNO, UNESCO, UNICEF, etc.) have been struggling to keep peace in the world through Sustainable Development Education (SDE), So Pakistan is also striving for making peace by its educational policies and constitution. But despite the recognition of sustainable development promoting values in the education policies, no proper mechanism yet exists for their teaching. In a sound system of education, every Pakistani child must have the right to get education about leading challenges of his/her community. This situation requires institutionalizing sustainable development teaching activities.

In this piece of research, Sustainable Development was accepted as a sum total of seven values mentioned below. Prevalence of Sustainable Development Values (SDVs) in the on-going teaching practices in Pakistani Madrassahs was evidenced at a high level. The seven Sustainable Development Values were reorganized in descending rank order as per their prevalence in the Madrassah teachers' teaching practices.

1. Personal Ecology

2. Environmental Concern

3. Creativity

4. $\quad$ Future Orientation

5. Stewardship of Resources

6. Frugality/Simplicity

7. Efficiency/Industry

'Personal Ecology' was the most practiced value in Madrassah teachers' on-going teaching practices, and 'Efficiency/Industry' was the minimum. Though the condition of sustainable development education was not very discouraging and the description of seven SDVs showed its prevalence in Madrassahs teachers' practices. Nevertheless, there is a great room for improvement of the situation to give morally stronger, socially more active, and professionally more proficient persons to Pakistani society.

It has been deducted from the given study that heads of departments, mentors, and learners of the Madrassahs consist of unanimous views that the expectations for teaching SDVs are significantly greater than the prevailing teaching practices of SDVs. It leads to the conclusion that there is a more need for teaching Sustainable Development Values (SDVs) to the Madrassah students.

\section{Recommendation}

The regulatory bodies of Madrassahs of Punjab may suggest a separate course on Sustainable Development Values (SDVs) in its policy guidelines for the Madrassahs under its auspices.

\section{References}

Bergmark, U. (2007). Ethical learning through meetings with others. International Journal of Learning, 14(5), 105-112.

Berkowitz, M. W., Battistich, V. A., \& Bier, M. C. (2008). What works in character education: What is known and what needs to be known. Handbook of Moral and Character Education, 414431.

Brundtland, G. H. (1987). Brundtland report. Our common future. Comissão Mundial.

Campbell, C., \& Murray, M. (2004). Community health psychology: Promoting analysis and action for social change. Journal of Health Psychology, 9(2), 187-195.

Chilton, P. (2004). Analysing political discourse: Theory and practice. routledge.

Dekker, A. G., Brando, V. E., Anstee, J. M., Pinnel, N., Kutser, T., Hoogenboom, E. J., ... \& Malthus, T. J. (2002). Imaging spectrometry of water. In Imaging spectrometry (pp. 307-359). Springer, Dordrecht.

Elliott, J.A. (2006). An introduction to sustainable development. Oxon: Routledge

Marope, P., Chakroun, B., \& Holmes, K. (2015). Unleashing the potential: transforming technical and vocational education and training. UNESCO.

Nunnally, J. C., Bernstein, I. H. (1994). Psychometric Theory. Third edition. New York, McGraw Hill. 
Raco, M. (2005). Sustainable development, rolled-out neoliberalism and sustainable communities. Antipode, 37(2), 324-347.

Shah, M. (2008). Sustainable development. Retrieved August 10, 2019, from www.sciencedirect.com: https://www.sciencedirect.com/topics/earth-and-planetary-sciences/sustainable-development

Shaker, R. R. (2015). The spatial distribution of development in Europe and its underlying sustainability correlations. Applied Geograph , 35.

Singh, S. (2007). Education for sustainable development. Retrieved march 15, 2019, from https://en.reset.org/knowledge/advancing-sustainable-development-through-education-india

UNESCO. (2019). Education for Sustainability-From Rio to Johannesburg: Lessons learnt from a decade of commitment. Retrieved march 15, 2019, from http://unesdoc.unesco.org: http://unesdoc.unesco.org/images/0012/001271/127100e.pdf

UNICEF. (2018). Emergencies \& humanitarian action. Canada: United Nations of International Children Emergency Funds.

WCED, S. W. S. (1987). World commission on environment and development. Our Common Future, 17, 1-91.

Webb, J., \& Chaffer, C. (2016). The expectation performance gap in accounting education: A review of generic skills development in UK accounting degrees. Accounting Education, 25(4), 349367. 